\title{
Tree mode of death in Central Amazonia: Effects of soil and topography on tree mortality associated with storm disturbances
}

\author{
José Julio de Toledo ${ }^{\mathrm{a}, *}$, William E. Magnusson ${ }^{\mathrm{a}}$, Carolina V. Castilho ${ }^{\mathrm{b}}$, Henrique E.M. Nascimento ${ }^{\mathrm{c}}$ \\ a Instituto Nacional de Pesquisas da Amazônia - INPA, Coordenação de Pesquisas em Ecologia - CPEC, Av. André Araújo 2936, C.P. 478, 69011-970 Manaus, AM, Brazil \\ ${ }^{\mathrm{b}}$ Empresa Brasileira de Pesquisa Agropecuária - EMBRAPA, Centro de Pesquisa Agroflorestal de Roraima, BR 174, km 8, Distrito Industrial, 69301-970 Boa Vista, RR, Brazil

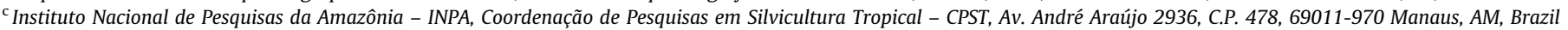

\section{A R T I C L E I N F O}

\section{Article history:}

Received 26 May 2011

Received in revised form 12 September

2011

Accepted 14 September 2011

Available online 28 October 2011

\section{Keywords:}

Forest dynamics

Permanent plots

Soil gradients

Topographic position

Treefall

Tropical forest

\begin{abstract}
A B S T R A C T
Tree mode of death provides insights as to why soil and topography explain only about $25 \%$ of the spatial variation in tree mortality in Central Amazonia, and permit predictions about what types of mortality are most probable under climate change. We studied tree mortality by mode of death in 72 1-ha permanent plots spanning $64 \mathrm{~km}^{2}$ of tropical moist forest in Reserva Ducke, Manaus, Amazonas, Brazil. Plots were recensused twice (2003-2005 and 2005-2008). Tree mode of death was assigned for trees $\geqslant 4 \mathrm{~cm} \mathrm{dbh}$ as standing, uprooted or snapped. We also recorded whether trees died alone or were pushed over by treefalls. Standing death was predominant, representing $54 \%$ of deaths of trees with $\mathrm{dbh} \geqslant 10 \mathrm{~cm}$, followed by snapping (26\%) and uprooting (14\%). Trees that fell alone represented $25 \%$ of deaths, while $16 \%$ were pushed over. Most small fallen dead trees $(4 \leqslant \mathrm{dbh}<30 \mathrm{~cm})$ were pushed over by other trees, while most large dead trees $(\mathrm{dbh} \geqslant 30 \mathrm{~cm}$ ) died alone. Standing mortality was weakly related to soil and topography, but $20 \%$ of variation in uprooted mortality and $11 \%$ in snapped mortality of trees with $\mathrm{dbh} \geqslant 10 \mathrm{~cm}$ was explained by soil and topography. The variation in mortality explained for small trees (18\% for uprooted mortality and $13 \%$ for snapped mortality) was higher than for large trees (14\% for mortality by snapping only). In spite of little variation in mortality associated directly with soil and slope, analyses assessing the effect of topographic categories (plateaux, slope, and valley) on tree mortality detected higher differences, even though causal factors remain unidentified because topographic position may encompass both topographic and soil properties. There was an increase from the first to the second census interval in the effects associated with soil and topography on tree mortality by uprooting and snapping, and this was likely due to storms, which led to a disproportional increase in tree mortality for these tree modes of death. Presently, uprooting and snapping mortality are not dominant and the use of soil and topographic variables for modeling of tree mortality is therefore limited. However, under predicted climate-change scenarios of higher frequency of extreme storms, soil and topography may become more useful to improve estimates of tree mortality and biomass losses over large areas in Amazonia.
\end{abstract}

(C) 2011 Elsevier B.V. All rights reserved.

\section{Introduction}

Soil and topography predict only about one-fourth of the mesoscale spatial variation in tree mortality in Central Amazonia (Toledo et al., 2011), which limits their use to improve predictions of mortality and biomass losses at regional scales. Although characteristics of soil and topography are associated with a larger proportion $(\sim 50 \%)$ of the variance in tree turnover rates among plots across Amazonia (Quesada et al., 2009), regional variation in soil properties is much larger (Quesada et al., 2011) than local-scale variation (Chauvel et al., 1987), and estimates of the relationships of forest structure and composition at local and mesoscales are

\footnotetext{
* Corresponding author. Tel.: +55 923643 1912; fax: +55 9236431925 .

E-mail address: jjuliotoledo@gmail.com (J.J. Toledo).
}

essential to make predictions with higher precision for larger domains (Laurance et al., 1999; Castilho et al., 2006, 2010; John et al., 2007; Costa et al., 2009; Ferry et al., 2010). Defining how tree mortality varies at local scales allows prediction of cumulative effects of mortality on biomass accumulation. In Central Amazonia, higher mortality on sandy soils (Toledo et al., 2011) is associated with higher losses and lower gains in biomass (Castilho et al., 2010), which results in higher variance of biomass stocks at mesoscales (Castilho et al., 2006). Constant high mortality apparently culminated in dominance of light-wood species of low stature and low biomass stocks in valleys in French Guiana (Ferry et al., 2010). Nevertheless, much of the mesoscale variation in tree mortality remains unexplained, which may be due to a lack of correlation between the true causes of tree death and the variables of soil and topography used as surrogates for causes of mortality. 
Mode of death can indicate the most probable agents of tree mortality. A higher proportion of trees tends to die standing in forests with low dynamism located in regions of stable climate and poor soils, but in Amazonian forests with higher mortality rates on richer soils with intense climatic disturbances, snapping and uprooting are the most important modes of tree death (Gale and Barfod, 1999; Chao et al., 2009). Previous studies have shown that tree mode of death varies with soil and topographic position at local scales. Trees often uproot on sandy and poorly drained soils in valleys and die standing in clayey soils with deep water tables on higher parts of the relief (e.g., Gale and Barfod, 1999; Gale and Hall, 2001). However, in areas of stable climatic conditions, proportions of each type of mortality may vary little with soil and topography (Chao et al., 2009). Central Amazonian forests are characterized by low dynamism, and tree mortality rates rarely exceed $1.5 \%$ year $^{-1}$ (e.g., Williamson et al., 2000; Nascimento and Laurance, 2004; Toledo et al., 2011). One of the reasons is that forest disturbances by connective windstorms (Nelson et al., 1994; Chambers et al., 2007), fires (Piperno and Becker, 1996), lightning strikes (Magnusson et al., 1996), and wet-season flooding (Mori and Becker, 1991) are limited in frequency and extent, further reducing tree mortality. However, high wind-driven mortality resulted in $0.3-0.5$ million dead trees in the Manaus region in January 2005 (NegrónJuárez et al., 2010). This represents nearly $30 \%$ of the observed annual deforestation reported in 2005 over the same area. To our knowledge, there was no quantification of the magnitude of the effect of mode of death on the relationships of soil and topography with tree mortality associated with storm disturbances. This is an important step to improve our understanding about causal factors of mortality and the relationship of mortality with environmental variables, as storm intensity is expected to increase under most climate-change scenarios (Marengo et al., 2009).

In Central Amazonia, the strength of the relationship between tree mortality and characteristics of soil and topography increased after storms (Toledo et al., 2011). Uprooting and snapping are modes of death often associated with storms, and are more frequent in the rainy season (Brokaw, 1985; Brandani et al., 1988; Denslow and Hartshorn, 1994). Intense rain and wind may increase the proportion of uprooting and snapping on steep slopes and at gap-edges. Trees often develop asymmetrical crowns in the downslope direction and into gaps because of more light availability (Young and Hubbell, 1991; Young and Perkocha, 1994), and an increase in the forces acting on the canopy due to rain or wind may cause root or stem failure, resulting in uprooting or snapping (Brokaw, 1985; Gale and Barfod, 1999). Nonetheless, standing death may occur due to a variety of causes which may, or may not, be associated with storms, such as lightning (Magnusson et al., 1996) or flooding (Mori and Becker, 1991; Gale and Hall, 2001), drought (Ashton and Hall, 1992), senescence (Alvarez-Buylla and Martinez-Ramos, 1992) or diseases (Gilbert and Hubbell, 1996).

A common methodological approach among studies relating tree mortality to topography or soil is prior classification of the landscape in topographic positions (e.g., Carey et al., 1994; Gale and Barfod, 1999; Gale and Hall, 2001; Ferry et al., 2010). Since categorization often implies loss of information, testing for the effect of topographic position using categorical surrogates may add uncertainties to estimation of the magnitude of the effects of predictor variables. Moreover, classification increases uncertainties as to which effect is being tested, because topography is a composite variable, which may, or may not, be a surrogate for gradients of soil texture, fertility, anchorage capacity, water availability, wind exposure, and flooding. The use of gradients of soil and topography to predict tree mortality is a more useful analytical approach for modeling because it is not necessary to create prior classifications, streamlining the process of extrapolation over larger domains
(Quesada et al., 2009; Toledo et al., 2011). Although the two approaches differ in the quality of the predictions, it is not clear whether they result in quantitative differences.

In this paper, we used data on tree mode of death, soil and topography, collected in 72 1-ha permanent plots between 2000 and 2008 in a tropical moist forest in Central Amazonia, to determine what types of tree mortality are predicted by soil and topography, and if the magnitude of the effect is sensitive to inter-annual variation in storm disturbances. Also, we evaluated the differences between analytical approaches using continuous variables and categories to represent topography.

\section{Methods}

\subsection{Study area}

The study was carried out in Reserva Ducke, which is managed by the Instituto Nacional de Pesquisas da Amazônia (INPA). The 10000-ha reserve is covered by relatively undisturbed terra firme tropical moist forest and is located on the periphery of the city of Manaus, Amazonas, Brazil $\left(2^{\circ} 55^{\prime} \mathrm{S}, 59^{\circ} 59^{\prime} \mathrm{W}\right.$; see Toledo et al., 2011 for details). The forest has a closed canopy of 30-37 m, with emergent trees reaching $45 \mathrm{~m}$ and an understory with abundant acaulescent palms. The dominant tree families are Fabaceae, Burseraceae, Sapotaceae, Lecythidaceae, Chrysobalanaceae, Moraceae and Lauraceae (Ribeiro et al., 1999).

Annual average temperature is $26^{\circ} \mathrm{C}$ and the average annual rainfall from 1979 to 2008 was $2524 \mathrm{~mm}$, with a dry season from July to September during which monthly rainfall is often around $100 \mathrm{~mm}$ (Coordenação de Pesquisas em Clima e Recursos Hídricos - CPCRH - INPA, unpublished data). In the study period (20002008), the lowest annual precipitation was $2045 \mathrm{~mm}$ in 2003 and the highest $3330 \mathrm{~mm}$ in 2008 . The most severe dry seasons occurred in 2003 and 2008, with 3 months having less than $100 \mathrm{~mm}$ of rainfall, and the most humid dry season occurred in 2004, when there was no recorded total monthly precipitation less than $100 \mathrm{~mm}$ (Supplementary material Fig. S1).

Topography in Reserva Ducke is hilly with elevation varying from 40 to $140 \mathrm{~m}$ above sea level (a.s.l.) (Ribeiro et al., 1999). Soil characteristics are related to topography, especially with respect to clay content, which is greatest in the higher parts of the relief (Chauvel et al., 1987; Castilho et al., 2006). Oxisols (in the US Soil Taxonomy; Ferrasols in the IUSS Working Group WRB, 2006) predominate on the plateaux, Ultisols (Acrisols) are more common on the slopes and Spodosols (Podzols) predominate in the valleys, usually near water. All soils in Reserva Ducke are acidic and poor in phosphorus, calcium, magnesium, sodium and potassium, while often high in aluminum (Chauvel et al., 1987).

\subsection{Sampling design}

A grid of 18 8-km trails, each separated by $1 \mathrm{~km}$, was installed in Reserva Ducke, encompassing $64 \mathrm{~km}^{2}$ (see Toledo et al., 2011). Between December 2000 and February 2003, 72 1-ha permanent plots were established along the east-west trails at least $1 \mathrm{~km}$ from each other. These plots are long and narrow $(250 \times 40 \mathrm{~m})$ and follow the topographic contours, thereby maintaining a constant elevation, minimizing variation in soil type and depth to the water table within the plot (Costa and Magnusson, 2010).

Castilho et al. (2006) used a hierarchical design to sample trees and palms (hereafter collectively called trees) in which diameter at breast height ( $\mathrm{dbh}$ ) was used to define the sampling area. Trees with $\mathrm{dbh} \geqslant 30 \mathrm{~cm}$ were sampled in 1 ha $(250 \times 40 \mathrm{~m})$, while trees with $\mathrm{dbh} \geqslant 10 \mathrm{~cm}$ and $\mathrm{dbh} \geqslant 1 \mathrm{~cm}$ were sampled in $0.5 \mathrm{ha}$ $(250 \times 20 \mathrm{~m})$ and 0.1 ha $(250 \times 4 \mathrm{~m})$, respectively. The dbh was 
measured to the nearest $1 \mathrm{~mm}$ at $1.3 \mathrm{~m}$ above ground. When deformities or buttresses were present, dbh was measured $50 \mathrm{~cm}$ above them, and the point of measurement recorded. All trees were mapped and marked with aluminum numbered tags.

\subsection{Mortality data}

A census was carried out when plots were established (20002003), a second was done between February 2003 and 2005, and a third (though the time interval began in March 2005), between August 2006 and February 2008. The first census interval, between the first and second censuses, averaged $2 \pm 0.03$ years (mean \pm standard deviation, range 1.98-2.21 years for the 72 plots) and the second census interval, between the second and third census, was $3.1 \pm 0.2$ years (2.9-3.6 years). The total census interval between the first and third censuses averaged $5.1 \pm 0.2$ years (4.9-5.8 years).

Tree mortality was determined in the second and third censuses. Trees were defined as dead by the absence of leaves, sap and loss of bark. Stems which disappeared or those which were broken or had no sap below the point of measurement also were recorded as dead. In the second census (2003-2005), dead trees were classified as standing or fallen, and in the third census (2005-2008), all dead trees $\geqslant 4 \mathrm{~cm} d b h$, including those dead in the second census, were classified in the following modes of death: (1) Standing - dead trees with intact crown branches on their standing stem or with crown debris scattered in all directions around the tree stump; (2) uprooted - the root plate upturned with soil attached; (3) snapped - dead trees with a broken trunk and a downed stem on which crown branches were often attached; and (4) others - category used for trees that could not be located, had been cut by humans and those unidentifiable due to advanced stage of stem decomposition. Fallen dead trees (uprooted or snapped) were also classified as "dead alone" if there was no evidence that their death had been caused by falling debris from another tree, and downed trees under another fallen tree, large branch or liana, which apparently died at the same time, were classified as "pushed".

The equation described by Sheil et al. (1995) was used to calculate the mortality rates by mode of death for each plot: $m=1-\left[1-\left(N_{0}-N_{1}\right) / N_{0}\right]^{1 / t}$, where $m$ is given as percent of trees dead per year, $N_{0}$ and $N_{1}$ are the number of stems at the beginning and end of the time interval $t$. Tree mortality rates were calculated for the first ( $\sim 2$ years), second ( $\sim 3$ years) and total census interval ( $\sim 5$ years). Dead trees that had been recruited during the study were not included in estimates for the total census interval.

\subsection{Soil and topographic data}

Six superficial soil sub-samples $(0-5 \mathrm{~cm}$ deep) were collected at 50 - $\mathrm{m}$ intervals along the center line of each plot, and these were mixed to form a composite sample per plot. Soil samples were dried at $105^{\circ} \mathrm{C}$, cleaned by removing stones and fine roots and then sieved (2-mm mesh size). Soil texture and $\mathrm{pH}$ were measured in the Soil Laboratory of the INPA Agronomy Department and soil chemical measurements were carried out in the EMBRAPA (Empresa Brasileira de Pesquisa Agropecuária) soil chemistry laboratory in Manaus. We used 15 soil variables: clay, silt and sand (particles $<0.002,0.002-0.05$ and $0.05-2 \mathrm{~mm}$, respectively), $\mathrm{pH}$, available phosphorus (P), $\mathrm{K}^{+}, \mathrm{Ca}^{2+}, \mathrm{Mg}^{2+}, \mathrm{Na}^{+}, \mathrm{Cu}^{+}, \mathrm{Fe}^{2+}, \mathrm{Mn}^{2+}, \mathrm{Zn}^{2+}$, exchangeable aluminum $\left(\mathrm{Al}^{3+}\right)$ and potential acidity $\left(\mathrm{Al}^{3+}+\mathrm{H}^{+}\right)$. More detailed descriptions of these variables are given in Castilho et al. (2006).

A professional surveyor determined altitude (m.a.s.l.) using a theodolite. Slope was estimated with a clinometer at five points along the plot and the mean slope was used for each plot (Castilho et al., 2006). Mean altitude was $76.06 \pm 20.09 \mathrm{~m}(39.4-109.8 \mathrm{~m})$ and mean of slope was $9.9 \pm 7.5^{\circ}\left(0.7-27^{\circ}\right)$.

The data described here are available online through the Brazilian Biodiversity Research Program (Programa de Pesquisa em Biodiversidade - PPBio) at <http://ppbio.inpa.gov.br/Eng/inventarios/ ducke/pterrestre>.

\subsection{Topographic positions}

In order to assess differences in modes of death in relation to topographic position, we classified plots as plateau, slope and valley using field observation and data on altitude, slope and percentage of clay. This is the most common subjective classification used for topography in the area (Ribeiro et al., 1999). Plots with altitude $\geqslant 65$ m.a.s.l. and slope $<12^{\circ}$ were classified as on plateaux, those with altitude $<65 \mathrm{~m}$ and slope $<12^{\circ}$ were classified as in valleys, and plots with ground angle $\geqslant 12^{\circ}$ were classified as on slopes. However, not all valleys are at low altitudes. Therefore, we compared this classification to subjective impressions obtained in the field. When doubt arose as to the classification, we applied an additional criterion using percentage of clay: plots on soils with clay $<20 \%$ were classified as in valleys, those with clay $\geqslant 60 \%$ were on plateaux and plots with clay between $20 \%$ and $60 \%$ were on slopes. Thus, 17 plots were classified as in valleys, 27 as on plateaux and 28 as on slopes.

\subsection{Data analysis}

Principal Components Analysis (PCA) was used to reduce the dimensionality of the 15 topsoil variables (Castilho et al., 2006; Toledo et al., 2011). The axes were used in the regression analyses and also to show overlap among topographic positions.

We calculated the proportion of dead trees and mortality rates according to tree mode of death for two groups, small $(4 \leqslant \mathrm{dbh}<30 \mathrm{~cm})$ and large $(\mathrm{dbh} \geqslant 30 \mathrm{~cm})$ trees, because these classes have distinct relationships of mortality with soil and topography (Toledo et al., 2011), and we also ran all analyses for trees $\mathrm{dbh} \geqslant 10 \mathrm{~cm}$ in order to allow comparisons with previous studies. We tested for the effect of size and mode of death on the proportion of dead trees using two-way ANOVA. Multiple-regression analysis was used to test for the combined effects of the first two PCA components (PC1 and PC2) and slope on tree mortality rates. In a previous study, we have detected high correlation between altitude and the soil textural gradient (PC1; $r=0.82$, $\mathrm{df}=70$, $P<0.001$ ), so they were not used together in the regression models. The other variables were weakly correlated (see Castilho et al., 2006; Toledo et al., 2011). We used a second analytical approach, to relate soil and topography to tree mortality using topographic positions, for which we used one-way ANOVA, testing for the effect of topographic position (plateau, slope and valley) for each tree group (small or large) and for each census interval (first, second and total). We used the software $\mathrm{R}$ version 2.10.1 ( $\mathrm{R}$ Development Core Team, 2009) for all analyses.

\section{Results}

\subsection{Soil gradients}

The first ordination axis (PC1) explained $37 \%$ of the variation in the original dataset and described a textural gradient between plots with greater clay content and those with greater sand content (Fig. 1). This axis was also positively correlated with $\mathrm{K}^{+}, \mathrm{Na}^{+}, \mathrm{Fe}^{2+}$, $\mathrm{Al}^{3+}$ and $\mathrm{Al}^{3+}+\mathrm{H}^{+}$and negatively correlated with $\mathrm{pH}$. A fertility gradient was described by the second axis (PC2), which explained $22 \%$ of the variation and was positively associated with $\mathrm{pH}, \mathrm{P}, \mathrm{K}^{+}, \mathrm{Ca}^{2+}$, 


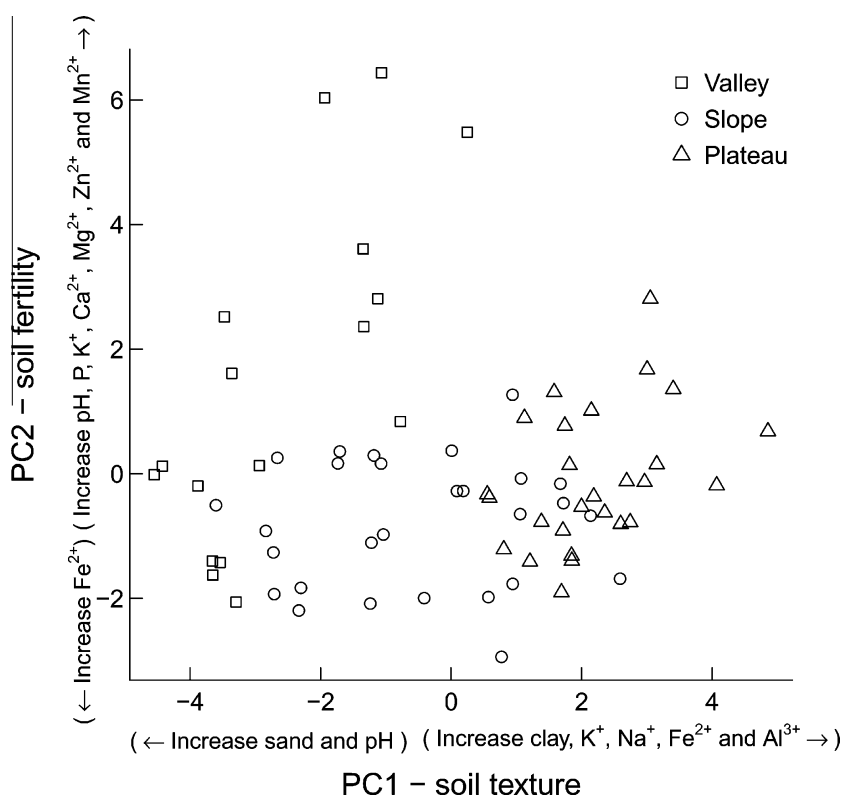

Fig. 1. Ordination of 72 1-ha plots using Principal Component Analysis based on 15 topsoil variables. The first (PC1) and second (PC2) axes explained $37 \%$ and $22 \%$ of variation, respectively. Symbols represent topographic positions where the plots are located.

$\mathrm{Mg}^{2+}, \mathrm{Zn}^{2+}$ and $\mathrm{Mn}^{2+}$, and negatively with $\mathrm{Fe}^{2+}$. Since we included sand in the analysis, the variation explained by each axis differed slightly from Castilho et al. (2006), but the gradients described were similar.

There was an obvious difference between plots on plateaux and those in valleys and slopes along the gradient described by the first PCA axis (Fig. 1). The second axis separated a few plots in valleys, which have higher concentrations of nutrients than other plots.

\subsection{The contribution of each mode of death}

We recorded 2320 dead trees with $\mathrm{dbh} \geqslant 4 \mathrm{~cm}$ between 2003 and 2008 in the 721 -ha plots, of which 1820 were small trees $(4 \leqslant \mathrm{dbh}<30 \mathrm{~cm})$ and 500 were large trees $(\mathrm{dbh} \geqslant 30 \mathrm{~cm})$. For trees with $\mathrm{dbh} \geqslant 10 \mathrm{~cm}, 1737$ were found dead.

Standing death was predominant, followed by snapping and uprooting (Fig. 2). For the total census (2003-2008), standing death represented 55\% ( $\pm 4 \% 95 \%$ confidence interval $-\mathrm{CI})$ and $53 \pm 6 \%$ of deaths of small and large dead trees, respectively. Snapped trees represented $24 \pm 3 \%$ of small dead trees and $28 \pm 5 \%$ of large dead trees, while uprooting contributed to $10 \pm 2 \%$ and $17 \pm 4 \%$ of deaths of small and large trees, respectively. The pattern was almost identical for trees with $\mathrm{dbh} \geqslant 10 \mathrm{~cm}$, for which $54 \pm 4 \%$ died standing, $26 \pm 3 \%$ snapped, and $14 \pm 3 \%$ were uprooted (Table 1 ).

Large fallen dead trees had died more often alone $(39 \pm 6 \%)$ than pushed ( $5 \pm 2 \%$; results from the total census interval), but for small fallen dead trees, pushed fallen trees $(23 \pm 4 \%)$ predominated over alone fallen dead $(14 \pm 3 \%)$ in the second census interval, although there was no significant differences between alone and pushed in the first and total census intervals (Supplementary material Fig. S2). Alone fallen dead trees were more frequent $(25 \pm 3 \%)$ than pushed fallen dead trees $(16 \pm 3 \%)$ in the total census interval when all trees with $\mathrm{dbh} \geqslant 10 \mathrm{~cm}$ were analyzed separately (Table 1 ).

From the first to the second census interval uprooting increased by $95 \%$ (Paired $t$-test: $t=-4.41, P<0.001$ ) and snapping increased by $44 \%$ (paired $t$-test: $t=-3, P=0.004, \mathrm{df}=71$ ) for small trees

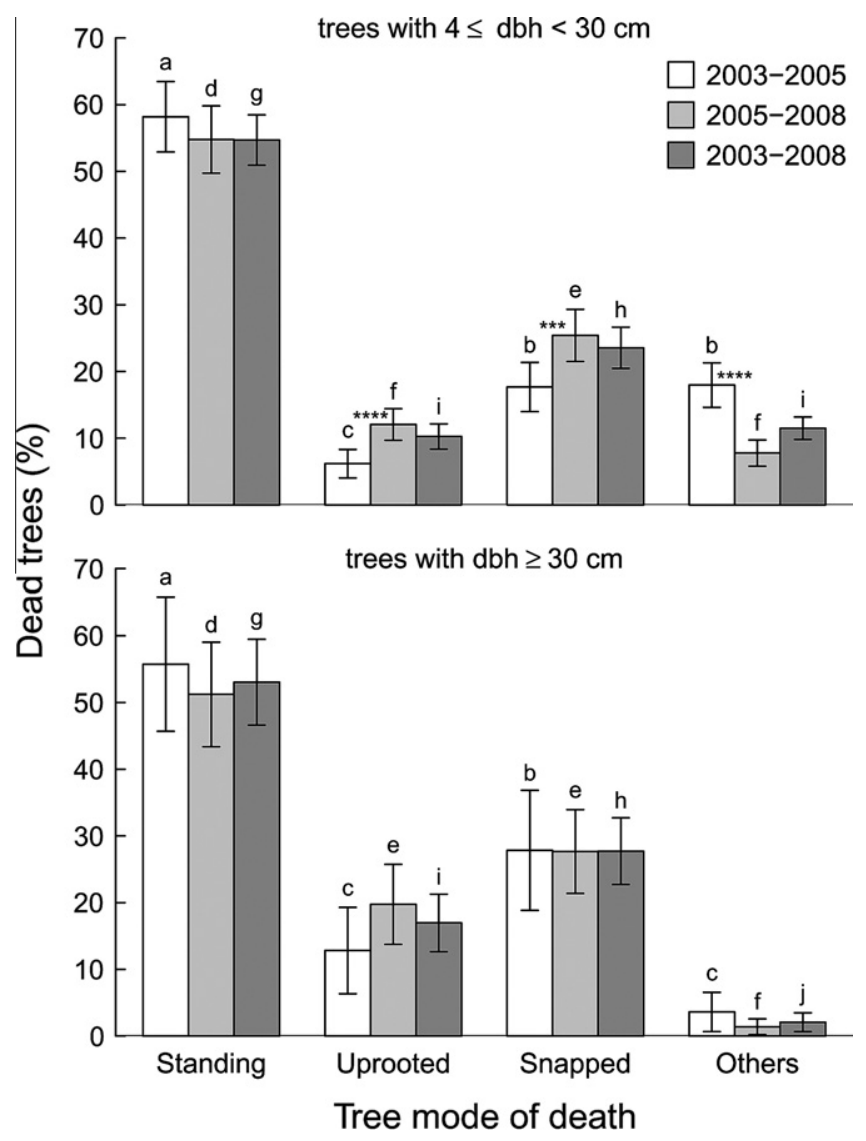

Fig. 2. Mean percentage ( $\pm 95 \% \mathrm{CI}$, vertical lines) of dead trees for modes of death in two dbh size classes in three census intervals. Asterisks indicate significant differences (paired $t$-test) between the first and second intervals $\left({ }^{* * *} P<0.01\right.$; ${ }^{* * * *} P<0.001$ ). Differences among modes of death within each census interval are indicated by different lower case letters after Tukey HSD post-hoc test at level of 0.1. Two-way ANOVA results for interaction between size and mode of death were: $F_{3,520}=7.30, P<0.001 ; F_{3,560}=3.35, P=0.02$; and $F_{3,568}=6.96, P<0.001$, for the first, second and total census intervals, respectively.

(Fig. 2). However, there was no significant change for large trees. For all trees with $\mathrm{dbh} \geqslant 10 \mathrm{~cm}$, uprooting increased by $67 \%$ (paired $t$-test: $t=-3.38, P=0.001, \mathrm{df}=71$; Table 1 ). Dead trees unclassified (Others) decreased in proportion in the second census because of more accurate identification of mode of death.

There was an increase of $57 \%$ (paired $t$-test: $t=-4.76, P<0.001$, $\mathrm{df}=71$ ) and $17 \%$ (paired $t$-test: $t=-1.75, P=0.09$, $\mathrm{df}=57$ ) in treefalls from the first to the second census interval for small and large trees, respectively (Supplementary material Fig. S2). However, for small trees only pushed fallen deaths increased (120\%; paired $t$ test: $t=-4.73, P<0.001, \mathrm{df}=71$ ), while for large trees only death alone increased (19\%; paired $t$-test: $t=-1.93, P=0.06, \mathrm{df}=57$ ). There was also an increase $(32 \%)$ in treefalls (uprooted plus snapped; paired $t$-test: $t=-3.17, P=0.002, \mathrm{df}=71$ ) from the first to the second census for trees with $\mathrm{dbh} \geqslant 10 \mathrm{~cm}$ (Table 1$)$. Pushed fallen dead trees increased by $84 \%$ (paired $t$-test: $t=-3.69$, $P<0.001, \mathrm{df}=71$ ) while death alone did not change significantly $(t=-0.93, P=0.35, \mathrm{df}=71)$.

\subsection{Mortality rates by mode of death related to soil and slope}

Little of the variation in mortality rates of any mode of death was related to soil or slope (Table 2, Supplementary material Tables S1 and S2). However, the magnitude of the effect of soil and slope on treefall (uprooted plus snapped) mortality increased from the first to the second census interval, probably due to 
Table 1

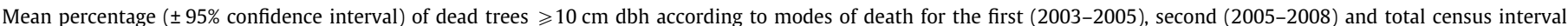

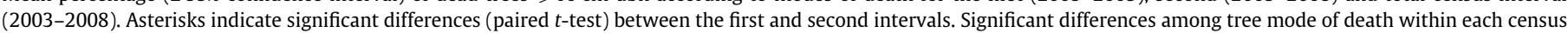

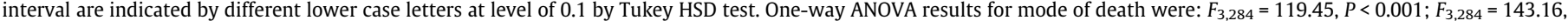
$P<0.001$; and $F_{3,284}=187.63, P<0.001$, for the first, second and total census interval, respectively

\begin{tabular}{|c|c|c|c|c|c|c|c|}
\hline Census Interval & Standing & Uprooted & Snapped & Others & Treefall & Alone & Pushed \\
\hline $1 \mathrm{st}$ & $59.03^{\mathrm{a}} \pm 5.88$ & $9.72^{\mathrm{c}} \pm 3.35$ & $22.79^{b} \pm 4.66$ & $8.47^{\mathrm{c}} \pm 2.55$ & $32.51 \pm 5.49$ & $22.60 \pm 4.28$ & $9.90 \pm 3.21$ \\
\hline 2nd & $53.71^{d} \pm 5.08$ & $16.23^{\mathrm{f}^{* * *}} \pm 3.24$ & $26.69^{e} \pm 3.62$ & $3.37^{\mathrm{g} * * * *} \pm 1.18$ & $42.92^{* * *} \pm 4.93$ & $24.67 \pm 3.05$ & $18.24^{* * * * *} \pm 3.60$ \\
\hline Total & $54.07^{\mathrm{h}} \pm 4.44$ & $14.42^{\mathrm{j}} \pm 2.71$ & $26.27^{\mathrm{i}} \pm 3.12$ & $5.24^{\mathrm{k}} \pm 1.14$ & $40.69 \pm 4.25$ & $24.49 \pm 2.83$ & $16.20 \pm 2.78$ \\
\hline
\end{tabular}

$P<0.01$.

$P<0.001$.

storms, which increased disproportionately tree uprooting and snapping. Possibly as a result of the higher mortality in the second census, most of the results in the total census interval mirrored the patterns of the second census. Therefore, we generally report the results from the total census interval, and only present results from the first or second intervals when they diverge from those of the total.

In the total census, $18 \%$ of variation in uprooting mortality of small trees $(4 \leqslant \mathrm{dbh}<30 \mathrm{~cm})$ was associated $\left(F_{3,68}=5.05\right.$, $P=0.003$ ) with soil and slope (Table 2 ). Uprooting mortality was positively related to the soil-fertility gradient (PC2; $t=1.96$, $P=0.05)$ and slope $(t=3.21, P=0.002)$, indicating higher mortality by uprooting on plots with higher concentration of nutrients and on steep slopes. Less variation (14\%) in uprooting mortality of large trees $(\mathrm{dbh} \geqslant 30 \mathrm{~cm})$ was explained by soil and slope $\left(F_{3,68}=3.83\right.$, $P=0.01$ ), but the patterns of the relationships were similar to those observed for small trees (Table 2).

Snapping mortality of small trees was higher $\left(F_{3,68}=3.49\right.$, $P=0.02)$ on more fertile soils since the soil-fertility gradient was positively related $(t=2.71, P=0.009)$ to tree mortality by snapping (Table 2$)$. However, little of the variance (13\%) was explained.

Soil and slope predicted only $10 \%$ of variance in standing mortality of small trees and only in the second census interval $\left(F_{3,68}=2.45, P=0.07\right)$. Standing mortality was negatively related to the soil textural gradient $(t=-1.95, P=0.06)$, unexpectedly indicating that fewer trees died standing on clayey soils on plateaux.

Treefall mortality of small trees was also higher on fertile soils $(t=2.71, P=0.009)$ and on steep slopes $(t=2.06, P=0.04)$, but also little variance $\left(16 \% ; F_{3,68}=4.34, P=0.007\right.$ ) was explained (Supplementary material Table S1). Slightly more variation was explained for mortality calculated for alone fallen dead trees (22\% in the second census interval; $F_{3,68}=6.57, P<0.001$ ), with higher mortality on more fertile soils $(t=3.41, P=0.001)$ and on steep slopes $(t=2.78, P=0.007)$. For large trees, only mortality for alone fallen dead trees was related to the gradients, positively with soil fertility $(t=1.98, P=0.05)$ and slope $(t=2.08, P=0.04)$, but only $11 \%$ of the variance was accounted for $\left(F_{3,68}=2.73, P=0.05\right)$.

The relationships of mortality rates of trees with $\mathrm{dbh} \geqslant 10 \mathrm{~cm}$ with the gradients of soil and slope (Supplementary material Table S2) showed the same patterns as mortality of trees with $4 \leqslant \mathrm{dbh}<30 \mathrm{~cm}$. Slightly more variance was explained for uprooting mortality (20\% against $18 \%$ for trees $4 \leqslant \mathrm{dbh}<30 \mathrm{~cm}$ ) and slightly more variance was explained for snapping mortality $(11 \%$ against $13 \%$ ), but the relationships with soil fertility and slope were still posititve.

\subsection{Differences in mortality between topographic positions}

Despite low variance explained and low magnitude of the effect of soil and slope on mortality rates, topographic categories and mortality were highly related. Overall mortality of small trees increased by $40 \%$ from plateaux to valleys, but mortality by uprooting was more than twice as high in valleys and slopes than on plateaux for small and large trees in the total census interval (Table 3 and Supplementary material Table S3). Snapped and treefall mortality were also higher ( $63 \%$ and $80 \%$, respectively) in valleys than on plateaux, and mortality for alone fallen dead trees doubled from plateaux to valleys. However, standing mortality was not related to topographic position.

In the first census interval, mortality by uprooting of small and large trees, and treefall and pushed mortality of small trees were higher on slopes than on plateaux (Supplementary material Tables S4 and S3), which may be an indication that under stable climatic conditions, wind exposure on slopes may be more critical for treefall than variation in soil, nutrient and water-table depth. Alone mortality of small trees was higher in valleys than on plateaux. Mortality in the second census was higher and showed the same trends as described for the total census interval.

Mortality rates of trees with $\mathrm{dbh} \geqslant 10 \mathrm{~cm}$ were related to topographic position (Supplementary material Tables S5 and S6) and the patterns followed those for mortality of trees with $4 \leqslant \mathrm{dbh}<30 \mathrm{~cm}$. Some discrepancies, such as the absence of differences in snapped mortality related to topography in the total census interval may be due to the exclusion of trees with $\mathrm{dbh}<10 \mathrm{~cm}$, which are more prone to be snapped in valleys, where there was higher alone treefall mortality.

\section{Discussion}

\subsection{Tree mortality by mode of death}

Since we classified dead trees as uprooted and snapped in the second census, the increase from the first to the second interval could be a result of errors associated with the classification of trees that died in the first census. However, because dead trees were previously classified as standing or treefall in the first census by one of us (Castilho), we have confidence in the patterns shown for treefall mortality.

More than half $(54 \%)$ of the dead trees with $\mathrm{dbh} \geqslant 10 \mathrm{~cm}$ died standing in Reserva Ducke, and only $14 \%$ uprooted and 26\% were snapped. Therefore, senescence is probably important in the process of tree mortality in Central Amazonian forests, as a result of high wood density of trees (Nogueira et al., 2005), dominance of infertile deep clayey soils (Chauvel et al., 1987) and relatively unseasonal climate. The same pattern was reported for northeastern Amazonian forests in Venezuela, in which $48 \%$ died standing, $35 \%$ uprooted and 18\% were snapped (Chao et al., 2009). In Paracou, French Guiana, $48 \%$ of dead trees died standing and $52 \%$ in treefalls (Ferry et al., 2010). For dead trees with $\mathrm{dbh} \geqslant 20 \mathrm{~cm}$, in Andalau forest (North Borneo), 46\% died standing, 14\% were uprooted and $11 \%$ were snapped, and in Danum (East Malaysia) $37 \%, 14 \%$ and $22 \%$ were recorded as standing, uprooted and snapped, respectively (Gale and Hall, 2001). All these forests share similarities with forests in Central Amazonia, such as high wood density, infertile deep soils and relatively infrequent storm disturbances (Carey et al., 1994; Gale and Hall, 2001; Chao et al., 2009; 
Table 2

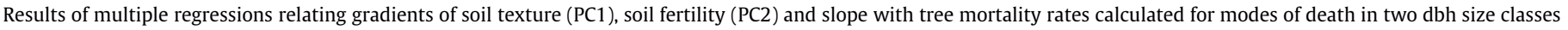
in three census intervals: first (2003-2005); second (2005-2008); and total census interval (2003 -2008).

\begin{tabular}{|c|c|c|c|c|c|c|c|c|}
\hline \multirow[t]{2}{*}{ dbh Classes $(\mathrm{cm})$} & \multirow[t]{2}{*}{ Mode of death } & \multirow[t]{2}{*}{ Census interval } & \multicolumn{3}{|c|}{ Standard Partial Slope $(b)$} & \multirow[t]{2}{*}{$F^{\mathrm{a}}$} & \multirow[t]{2}{*}{$P$} & \multirow[t]{2}{*}{$R^{2}$} \\
\hline & & & PC1 & PC2 & Slope & & & \\
\hline \multirow[t]{9}{*}{$\geqslant 4,<30$} & \multirow[t]{3}{*}{ Standing } & $1 \mathrm{st}$ & -0.09 & -0.04 & -0.03 & 0.19 & 0.90 & 0.01 \\
\hline & & 2nd & $-0.23^{*}$ & 0.17 & 0.12 & 2.45 & 0.07 & 0.10 \\
\hline & & Total & $-0.22^{*}$ & 0.09 & 0.07 & 1.56 & 0.21 & 0.06 \\
\hline & \multirow[t]{3}{*}{ Uprooted } & $1 \mathrm{st}$ & -0.17 & 0.02 & $0.26^{* *}$ & 2.96 & 0.04 & 0.12 \\
\hline & & 2nd & -0.08 & $0.27^{* *}$ & $0.38^{* * *}$ & 4.49 & 0.006 & 0.17 \\
\hline & & Total & -0.12 & $0.23^{*}$ & $0.39^{* * * *}$ & 5.05 & 0.003 & 0.18 \\
\hline & \multirow[t]{3}{*}{ Snapped } & $1^{\text {st }}$ & -0.12 & 0.09 & 0.001 & 0.52 & 0.67 & 0.02 \\
\hline & & $2^{\text {nd }}$ & -0.13 & $0.32^{* *}$ & 0.12 & 2.94 & 0.04 & 0.11 \\
\hline & & Total & -0.17 & $0.33^{* * *}$ & 0.12 & 3.49 & 0.02 & 0.13 \\
\hline \multirow[t]{9}{*}{$\geqslant 30$} & \multirow[t]{3}{*}{ Standing } & $1 \mathrm{st}$ & -0.05 & -0.08 & 0.04 & 0.30 & 0.83 & 0.01 \\
\hline & & 2nd & -0.08 & $-0.22^{*}$ & $-0.27^{* *}$ & 1.82 & 0.15 & 0.07 \\
\hline & & Total & -0.10 & $-0.23^{*}$ & $-0.23^{*}$ & 1.54 & 0.21 & 0.06 \\
\hline & \multirow[t]{3}{*}{ Uprooted } & $1 \mathrm{st}$ & -0.01 & 0.19 & $0.25^{*}$ & 1.62 & 0.19 & 0.07 \\
\hline & & 2nd & -0.15 & 0.21 & $0.22^{*}$ & 2.46 & 0.07 & 0.10 \\
\hline & & Total & -0.13 & $0.27^{* *}$ & $0.31^{* *}$ & 3.83 & 0.01 & 0.14 \\
\hline & \multirow[t]{3}{*}{ Snapped } & $1 \mathrm{st}$ & -0.11 & -0.07 & -0.03 & 0.32 & 0.81 & 0.01 \\
\hline & & 2nd & 0.05 & 0.14 & 0.02 & 0.47 & 0.70 & 0.02 \\
\hline & & Total & -0.05 & 0.07 & -0.004 & 0.17 & 0.92 & 0.01 \\
\hline
\end{tabular}

${ }^{*} P<0.1$.

** $P<0.05$.

**** $P<0.01$

a Three and 68 degrees of freedom.

Ferry et al., 2010), which allow deep rooting and prevent tree uprooting and snapping. Uprooting and snapping are relatively more frequent in Western Amazonian forests, due to higher frequency of low-wood-density trees (Baker et al., 2004), storm disturbances, high rainfall and shallow younger soils, with median to low clay contents, which offer low adherence for roots (Quesada et al., 2011). In Northern Peru, $20 \%$ of dead trees died standing, $30 \%$ were uprooted and 50\% snapped (Chao et al., 2009). In Cuyabeno (Eastern Ecuador), 20\% were found standing, 42\% uprooted and $38 \%$ snapped (Korning and Balslev, 1994), and in Hoja Blanca (Western Ecuador), only 15\% were found standing, but 34\% were uprooted and 35\% snapped.

Although we have analyzed short-term data, the increase in the proportion of uprooting and snapping in the second interval indicates the effects of storms. In January 2005, a single squall line (cluster of convective storm cells) propagated across Central Amazonia with downburst velocities between 26 and $41 \mathrm{~m} \mathrm{~s}^{-1}$, which are sufficient to cause large-scale forest tree mortality (Negrón-Juárez et al., 2010). This event was associated with blowdowns recorded in forests $\sim 50 \mathrm{~km}$ northwest of Reserva Ducke (Chambers et al., 2007). Two permanent large plots close to this location experienced the highest tree mortality since 1996 (Souza, 2011). Phillips et al. (2009) associated the high mortality in Central Amazonia only to the 2005 drought, but rainfall and local river discharge demonstrated that the drought had little effect in Central Amazonia (Marengo et al., 2008). Indeed, the drought in 2005 was not severe in Reserva Ducke (Supplementary material Fig. S1).

Increase in forest dynamism can provoke changes in the forest composition which in turn affect carbon cycling. Under higher mortality and recruitment, the predominance of fast-growing and light-demanding species with light wood density is expected, as in the Western Amazonian forests (Baker et al., 2004). There is evidence that floristic composition of Central Amazonian forests is changing (Laurance et al., 2004). Fast-growing emergent and canopy tree genera are increasing in density while many smaller and old-growth subcanopy trees are decreasing. Local variation in stocks and changes of biomass (Laurance et al., 1999; Castilho et al., 2006, 2010) may be partly due to local variation in species composition, as a consequence of mortality differences at mesoscales (Toledo et al., 2011). The decrease in subcanopy species may be irreversible under climate change scenarios of higher frequency of heavy rains (Marengo et al., 2009), since death by uprooting or snapping of large trees may increase and, consequently, increase the mortality of subcanopy trees. However, continuous monitoring of forest mortality and composition will be needed to determine whether changes are consequences of climate change or part of a post-disturbance regeneration process of forest patches (Nelson, 2005).

\subsection{The effect of soil and slope on different types of tree mortality}

We showed that the relationships of tree mortality with soil and topography found by Toledo et al. (2011) are restricted mainly to treefall mortality (uprooting, snapping and alone treefall mortality). Uprooting mortality was positively related to soil fertility and slope, following the patterns of all types of mortality combined. Espeleta and Clark (2007) showed that biomass and production of fine roots ( $<5 \mathrm{~mm}$ in diameter) was lower on fertile soils than on poor soils, possibly because trees do not need to invest in a large root system where nutrients are not limiting, but this may cause tree anchorage to be less efficient on fertile soils. Quesada et al. (2009) found a positive relationship between soil fertility and tree mortality at regional scales in Amazonia. However, soil physical properties are related to soil fertility, which makes it difficult to identify causal factors related to uprooting. We had similar difficulties in this mesoscale study in Reserva Ducke, since plots with the highest concentration of nutrients are on sandy soils and showed the highest mortality by uprooting. Furthermore, sandy soils in this region are also generally associated with small streams, and have a shallow water table (Tomasella et al., 2008). The higher proportion of uprooted dead trees in valleys in Amazonia and French Guiana has been attributed to poor soil drainage (Durrieu de Madron, 1994; Gale and Barfod, 1999; Ferry et al., 2010). Excess water in the soil restricts root establishment because productivity of fine roots and rooting depth are generally low on sandy soils and soils with high moisture content (Schenk and Jackson, 2002; Espeleta and Clark, 2007). Although we did not directly measure water-table depth in the plots, which would be strongly associated to tree mortality and modes of death, the soil-fertility gradient may be a surrogate for soil waterlogging because this 
Table 3

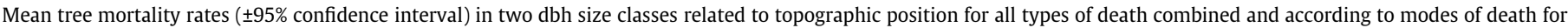

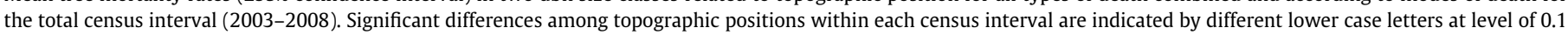
by Tukey HSD test (see Supplementary Material Table S3 for ANOVA results).

\begin{tabular}{|c|c|c|c|c|c|c|c|c|}
\hline \multirow[t]{2}{*}{ Dbh Classes (cm) } & \multirow[t]{2}{*}{ Topographic position } & \multicolumn{7}{|l|}{ Mortality (\% year ${ }^{-1}$ ) } \\
\hline & & All types combined & Standing & Uprooted & Snapped & Treefall & Alone & Pushed \\
\hline \multirow[t]{3}{*}{$\geqslant 4,<30$} & Valley & $1.58^{\mathrm{a}} \pm 0.34$ & $0.75 \pm 0.13$ & $0.18^{\mathrm{a}} \pm 0.10$ & $0.44^{\mathrm{a}} \pm 0.15$ & $0.63^{\mathrm{a}} \pm 0.23$ & $0.27^{\mathrm{a}} \pm 0.09$ & $0.35 \pm 0.16$ \\
\hline & Slope & $1.45^{\mathrm{a}} \pm 0.22$ & $0.70 \pm 0.09$ & $0.22^{\mathrm{a}} \pm 0.06$ & $0.32^{\mathrm{ab}} \pm 0.08$ & $0.54^{\mathrm{ab}} \pm 0.13$ & $0.22^{\mathrm{a}} \pm 0.05$ & $0.32 \pm 0.10$ \\
\hline & Plateau & $1.13^{\mathrm{b}} \pm 0.15$ & $0.65 \pm 0.08$ & $0.08^{\mathrm{b}} \pm 0.04$ & $0.27^{\mathrm{b}} \pm 0.08$ & $0.35^{\mathrm{b}} \pm 0.11$ & $0.13^{\mathrm{b}} \pm 0.05$ & $0.22 \pm 0.08$ \\
\hline \multirow[t]{3}{*}{$\geqslant 30$} & Valley & $1.59 \pm 0.52$ & $0.57 \pm 0.22$ & $0.43^{\mathrm{ab}} \pm 0.33$ & $0.47 \pm 0.20$ & $0.93 \pm 0.51$ & $0.83 \pm 0.44$ & $0.09 \pm 0.09$ \\
\hline & Slope & $1.64 \pm 0.40$ & $0.73 \pm 0.16$ & $0.42^{\mathrm{a}} \pm 0.19$ & $0.39 \pm 0.15$ & $0.83 \pm 0.29$ & $0.73 \pm 0.26$ & $0.09 \pm 0.09$ \\
\hline & Plateau & $1.35 \pm 0.23$ & $0.75 \pm 0.16$ & $0.15^{\mathrm{b}} \pm 0.07$ & $0.42 \pm 0.14$ & $0.57 \pm 0.18$ & $0.46 \pm 0.14$ & $0.11 \pm 0.07$ \\
\hline
\end{tabular}

gradient was positively correlated to available phosphorus $(r=0.53, \mathrm{df}=70, P<0.001)$ and negatively correlated to $\mathrm{Fe}^{2+}$ $(r=-0.48, \mathrm{df}=70, P<0.001)$. High available phosphorus and low $\mathrm{Fe}^{2+}$ are associated with waterlogged soil since microbial activity under depleted soil redox potential releases phosphate anion which is chemically sorbed to iron oxides and can reduce $\mathrm{Fe}^{2+}$ to insoluble FeS (Baldwin and Mitchel, 2000). Therefore, despite the higher uprooting mortality on fertile soils, other factors such as soil physical properties and flooding may have a synergistic effect on tree uprooting.

The positive relationship between snapping mortality and soil fertility may be explained by the high dynamics of forest patches which lead to different floristic composition on more fertile soils in Reserva Ducke. Although biomass stocks and biomass changes were not related to the soil-fertility gradient in our site (Castilho et al., 2006, 2010), all types of tree mortality combined were positively related to this gradient (Toledo et al., 2011). Disturbed sites have higher probability of being re-disturbed. Pre-existing large gaps ( $>375 \mathrm{~m}^{2}$ ) experienced more canopy disturbance than smaller gaps or undisturbed sites in Barro Colorado Island (Young and Hubbell, 1991). Shorter trees $(<23 \mathrm{~m})$ at gap-edges fell more frequently in the gap direction than other directions. The constant regime of disturbance and recovering on more fertile soils may change tree species composition. There is evidence of changes in floristic composition along the soil gradients in Reserva Ducke (Castilho, unpublished data) since mean species-level wood density per plot is negatively correlated to the soil-fertility gradient $(r=-0.63, P<0.001, \mathrm{df}=70)$, indicating the predominance of low-wood-density species in valleys. Fast-growing species may be more abundant in forest patches on more fertile soils because nutrient supplies are not limiting. Due to the need to grow fast to compete for space and light, these species develop wood tissues of low density which may be more susceptible to failure (AlvarezBuylla and Martinez-Ramos, 1992; Chao et al., 2008), thereby increasing snapping.

Uprooting and snapping mortality were higher on steep slopes. Although mortality may be highly variable on weak slopes, because of the contrasting mortality between valleys and plateaux which are flat, slope angle may explain part of the variation in mortality which is not associated with soil texture, nutrients and depth to the water table. Slope angle may have a direct effect on tree uprooting and snapping because trees may have centers of gravity dislocated from the base of the tree on steep slopes (Robert, 2003). Despite the development of more roots or buttressed roots to remain standing (Young and Perkocha, 1994), storms finally cause tree snapping or uprooting. Furthermore, in Reserva Ducke, trees may uproot on slopes because soils are rich in sand ( $\sim 57 \%)$, and the water table is shallow in the transition between slope and valley (Tomasella et al., 2008). Gale and Barfod (1999) argued that shallow soils were the main cause of tree uprooting in Ecuador, but most soils on slopes in Reserva Ducke are deep (Chauvel et al., 1987).
Despite the predominance of standing dead trees $(>50 \%)$, this type of mortality was only related to the soil textural gradient. Unexpectedly, standing mortality was lower on clayey soils on plateaux than on sandy soils in valleys, which contrast to the results obtained in most studied sites in tropical forests, where a higher proportion of standing dead trees was found on well-drained soils in the higher parts of the relief (Gale and Barfod, 1999; Gale and Hall, 2001). Trees die standing due to several factors, including disease, senescence, lightning and competition, but good anchorage, stem resistance and climatic stability are essential to keep a dying tree standing. Comparisons between plots in northwestern and northeastern Amazonia on similar unfertile soils (mostly ultisols) revealed that standing mortality is higher in the northeast where the climate is more stable than in the northwest (Chao et al., 2009). Snapping was higher in the northwest, probably as a result of unstable climate and the predominance of light-wood tree species, which are not able to stand against wind or falling trees. Soil waterlogging may also cause standing death (Mori and Becker, 1991), and this type of death may have occurred after storm disturbances, but the reasons for this pattern are unclear.

This study showed an increase in the magnitude of the effect of soil and slope on treefall mortality, possibly due to storms which occurred in 2005 in the region (Chambers et al., 2007; NegrónJuárez et al., 2010). Higher frequency of treefalls and gap formation in La Selva (Costa Rica) and in Barro Colorado Island (Panamá) took place in the rainy season (Brokaw, 1985; Brandani et al., 1988; Denslow and Hartshorn, 1994). Under climate-change scenarios of more frequent extreme rains in Amazonia (Marengo et al., 2009), the rates of uprooting and snapping may increase substantially. Therefore, in a more dynamic forest with higher mortality, the effectiveness of soil and topography to predict variation in tree mortality may increase.

\subsection{The effect of topographic position}

Topography is a composite variable, and may represent variation in wind exposure, resistance for anchorage, light and water availability, soil texture or fertility. Investigating the effect of topography on tree mortality is essential to make predictions over larger areas (Ferry et al., 2010). However, the composite nature of topography only allows speculations on the causal factors of different types of mortality (Gale and Barfod, 1999; Gale and Hall, 2001; Ferry et al., 2010).

In contrast to our results, treefall mortality on slopes was similar to that on hilltops in French Guiana (Ferry et al., 2010); however, slope in our site may encompass the categories of slope and downslope used by Ferry et al. (2010). Moreover, some plots classified as slope may have been classified as valley and vice-versa, because we have no data on water table depth to set precise limits between these categories. Treefall mortality in bottomlands in French Guiana was 37\% higher than in valleys in Reserva Ducke, suggesting that waterlogging is more severe in the former. On 
the other hand, treefall mortality on slopes $\left(0.54 \%\right.$ year $\left.^{-1}\right)$ in Reserva Ducke was similar to those for slope (0.50) and downslope (0.56) in French Guiana. Treefall mortality on hilltops (0.42) in French Guiana showed slightly higher mortality than in Reserva Ducke (0.35), which may be due to more limited permeability of soils in the French Guiana site (Epron et al., 2006).

The relationships between the continuous variables of soil and slope and tree mortality indicate that variation in mortality is weakly related to, and thus poorly explained by, those environmental variables. However, the large differences in tree mortality between topographic positions from the same dataset indicate that tree mortality is related to topography and varies greatly between valleys and plateaux. Nevertheless, testing for the effect of topographic positions may increase the probability of finding larger differences because of the strong inference about weak categories (Platt, 1964). The use of categories implies overlap of similar environmental conditions and loss of information on the predictor variables. In this case, topographic positions enclose several factors and we are not able to identify which variable is more critical for tree mortality. Testing for the relationships between continuous variables and tree mortality allows us to make a weak inference about a strong category (each variable). Further, this method quantifies the variance explained which can be used as a measure of confidence for initial modeling. Gross categories will not explain why the effect of topographic position varies among localities, or allow effective modeling of effects of climate change.

The use of topographic positions as predictors may be an efficient approach to assess whether differences in rates of mortality, or differences in the proportions of modes of death, exist or not in relation to topography, but as a tool for predict variation of mortality over larger domains, categorical predictors are inefficient. Ferry et al. (2010) used an interesting sub-plot design to show that treefall mortality increased by a factor of two from plateaux to valleys and that all types of mortality combined increase by $50 \%$. They concluded that site characteristics must be included in the process of scaling up the results. We found an $80 \%$ increase in treefall mortality from plateaux to valleys, a two fold increase in alone treefall mortality and $40 \%$ increase for all types of mortality combined. Despite the differences in plot designs and census intervals, our results corroborate Ferry's et al. (2010). However, with the same dataset we also showed that soil and topography explain little of the variation in tree mortality, and further, we add more restrictions to models that attempt to predict mortality using soil and topography because only some types of mortality were related to soil and slope. Thus, we can draw two different conclusions from our dataset applying different analytical approaches. Although soil and slope may not incorporate all factors which are embedded in topography, both predictors may act directly on mortality and are more precise measures for site characterization and for modeling of mortality than topographic positions.

Alone treefall mortality had the highest association with soil and slope (20\% of the variance explained for small trees and trees with $\mathrm{dbh} \geqslant 10 \mathrm{~cm}$ ). However, this type of mortality represented only $14 \%$ of small and $25 \%$ of dead trees with $\mathrm{dbh} \geqslant 10 \mathrm{~cm}$. Standing mortality, which represented more than half of dead trees, was weakly related to the gradients. Thus our capacity to predict mortality over the landscape with soil and topography is restricted mainly to mortality associated with storm disturbances. To improve the models, we need to include factors which explain standing mortality. These variables could be descriptors of diseases, senescence, lightning and competition (Alvarez-Buylla and Martinez-Ramos, 1992; Magnusson et al., 1996; Gilbert and Hubbell, 1996; Gale and Barfod, 1999; Gale and Hall, 2001). Chao et al. (2009) have shown that tree size, growth rate and wood density were effective to determine if a tree will die standing or downed. However, the models were parameterized for individual trees.
Predicting tree mortality with biological characteristics at plot level is a more complex task since the biological variables will come from the tree community in the plot, which is a group of organisms having species or individual variation in life history traits. A community level value of size, growth or wood density may not be able to predict death of all individuals in a plot.

\section{Acknowledgements}

This contribution is part of the doctoral thesis of J.J.T. undertaken at the Instituto Nacional de Pesquisas da Amazônia (INPA), with fellowships from the Brazilian National Research Council (CNPq) during field work and from Coordenação de Aperfeiçoamento de Pessoal de Nivel Superior (CAPES) through Post-Doctorate National Program (PNPD) throughout manuscript elaboration. Gordon \& Betty Moore Foundation through Programa BECA - IEB (B/2006/ 01/BDP/04), CNPq/Universal (473989/2006-9) and the Brazilian Long-Term Ecological Research Program (CNPq/PELD \#520039/ 98-0) provided financial support. Logistical support was provided by PELD, INPA and Brazilian Biodiversity Research Program (PPBio). Data repositories are maintained by PPBio, PELD and the National Institute of Science and Technology for Amazonian Biodiversity (ICNT - CENBAM). We thank José S. Lopez, Oscinei S. Monteiro, F. Helena Aguiar and Paulo R. Pinto for help with field work, and two anonymous reviewers for useful comments and suggestions on the manuscript.

\section{Appendix A. Supplementary data}

Supplementary data associated with this article can be found, in the online version, at doi:10.1016/j.foreco.2011.09.017.

\section{References}

Alvarez-Buylla, E.R., Martinez-Ramos, M., 1992. Demography and allometry of Cecropia obtusifolia, a Neotropical pioneer tree - an evaluation of the climaxpioneer paradigm for tropical rain forests. J. Ecol. 80, 275-290.

Ashton, P.S., Hall, P., 1992. Comparisons of structure among mixed dipterocarp forests of north-western Borneo. J. Ecol. 80, 459-481.

Baker, T.R., Phillips, O.L., Malhi, Y., Almeida, S., Arroyo, L., Di Fiore, A., Erwin, T., Killeen, T.J., Laurance, S.G., Laurance, W.F., Lewis, S.L., Lloyd, J., Monteagudo, A. Neill, D.A., Patiño, S., Pitman, N.C.A., Silva, J.N.M., Martinez, R.V., 2004. Variation in wood density determines spatial patterns in Amazonian forest biomass. Glob. Change Biol. 10, 545-562.

Baldwin, D.S., Mitchel, A.M., 2000. The effects of drying and re-flooding on the sediment and soil nutrient dynamics of lowland river-floodplain systems: a synthesis. Regul. River 16, 457-467.

Brandani, A., Hartshorn, G.S., Orians, G.H., 1988. Internal heterogeneity of gaps and species richness in Costa Rican tropical wet forest. J. Trop. Ecol. 4, 99-119.

Brokaw, N.V., 1985. Treefalls, regrowth, and community structure in tropical forests. In: Pickett, S.T.A., White, P.S. (Eds.), The Ecology of Natural Disturbance and Patch Dynamics. Academic Press, Orlando, Florida, USA, pp. 53-69.

Carey, E.V., Brown, S., Gillespie, A.J.R., Lugo, A.E., 1994. Tree mortality in mature lowland tropical moist and tropical lower montane moist forests of Venezuela. Biotropica 26, 255-265.

Castilho, C.V., Magnusson, W.E., Araújo, R.N.O., Luizão, F.J., 2010. Short-term temporal changes in tree live biomass in a Central Amazonian forest, Brazil. Biotropica 42, 95-103.

Castilho, C.V., Magnusson, W.E., Araújo, R.N.O., Luizão, R.C.C., Luizão, F.J., Lima, A.P., Higuchi, N., 2006. Variation in aboveground tree live biomass in a Central Amazonian forest: effects of soil and topography. For. Ecol. Manag. 234, 85-96.

Chambers, J.Q. Asner, G.P., Morton, D.C., Anderson, L.O., Saatch, S.S., Espirito-Santo, F.D.B., Palace, M., Souza, C., 2007. Regional ecosystem structure and function: ecological insights from remote sensing of tropical forests. Trends Ecol. Evol. 22, 414-423.

Chao, K.J., Phillips, O.L., Gloor, E., Monteagudo, A., Torres-Lezama, A., Martinez, R.V., 2008. Growth and wood density predict tree mortality in Amazon forests. J. Ecol. 96, 281-292.

Chao, K.J., Phillips, O.L., Monteagudo, A., Torres-Lezama, A., Martinez, R.V., 2009 How do trees die? Mode of death in northern Amazonia. J. Veg. Sci. 20, 260-268.

Chauvel, A., Lucas, Y., Boulet, R., 1987. On the genesis of the soil mantle of the region of Manaus, Central Amazonia, Brazil. Experientia 43, 234-241.

Costa, F.R.C., Guillaumet, J.L., Lima, A.P., Pereira, O.S., 2009. Gradients within gradients: the mesoscale distribution patterns of palms in a central Amazonian forest. J. Veg. Sci. 20, 69-78. 
Costa, F.R.C., Magnusson, W.E., 2010. The need for large-scale, integrated studies of biodiversity - the experience of the Program for Biodiversity Research in Brazilian Amazonia. Braz. J. Nat. Conserv. 8, 3-12.

Denslow, J.S., Hartshorn, G.S., 1994. Tree-fall gap environments and forest dynamic processes. In: MacDade, L.A., Bawa, K.S., Hespenheide, H.A., Hartshorn, G.S. (Eds.), La Selva: Ecology and Natural History of a Neotropical Rain Forest. University of Chicago Press, Chicago, Illinois, USA, pp. 120-127.

Durrieu de Madron, L., 1994. Mortalité des arbres en forêt primaire de Guyane Française. Bois et Forêts des Tropiques 239, 43-57.

Epron, D., Bosc, A., Bonal, D., Freycon, V., 2006. Spatial variation of soil respiration across topographic gradient in a tropical rain forest in French Guiana. J. Trop. Ecol. 22, 565-574.

Espeleta, J.F., Clark, D.A., 2007. Multi-scale variation in fine-root biomass in a tropical rain forest: a seven-year study. Ecol. Monogr. 77, 377-404.

Ferry, B., Morneau, F., Bontemps, J.D., Blanc, L., Freycon, V., 2010. Higher treefall rates on slopes and waterlogged soils result in lower stand biomass and productivity in a tropical rain forest. J. Ecol. 98, 106-116.

Gale, N., Barfod, A.S., 1999. Canopy tree mode of death in a western Ecuadorian rain forest. J. Trop. Ecol. 15, 415-436.

Gale, N., Hall, P., 2001. Factors determining the modes of tree death in three Bornean rain forests. J. Veg. Sci. 12, 337-346.

Gilbert, G.S., Hubbell, S.P., 1996. Plant diseases and the conservation of tropical forests. Bioscience 46, 98-106.

IUSS (International Union of Soil Science) Working Group WRB, 2006. World reference base for soil resources 2006: a framework for international classification, correlation and communication. World Soil Resources Reports No. 103. FAO, Rome

John, R., Dalling, J.W., Harms, K.E., Yavitt, J.B., Stallard, R.F., Mirabello, M., Hubbell, S.P., Valencia, R., Navarrete, H., Vallejo, M., Foster, R.B., 2007. Soil nutrients influence spatial distributions of tropical tree species. Proc. Natl. Acad. Sci. USA 104, 864-869.

Korning, J., Balslev, H., 1994. Growth and mortality of trees in amazonian tropical rain-forest in Ecuador. J. Veg. Sci. 5, 77-86.

Laurance, W.F., Fearnside, P.M., Laurance, S.G., Delamonica, P., Lovejoy, T.E., Rankinde Merona, J., Chambers, J.Q., Gascon, C., 1999. Relationship between soils and Amazon forest biomass: a landscape-scale study. For. Ecol. Manag. 118, 127138.

Laurance, W.F., Oliveira, A.A., Laurance, S.G., Condit, R., Nascimento, H.E.M., Sanchez-Thorin, A.C., Lovejoy, T.E., Andrade, A., D’Angelo, S., Ribeiro, J.E., Dick, C.W., 2004. Pervasive alteration of tree communities in undisturbed Amazonian forests. Nature 428, 171-175.

Magnusson, W.E., Lima, A.P., deLima, O., 1996. Group lightning mortality of trees in a Neotropical forest. J. Trop. Ecol. 12, 899-903.

Marengo, J.A., Jones, R., Alves, L.M., Valverde, M.C., 2009. Future change of temperature and precipitation extremes in South America as derived from the PRECIS regional climate modeling system. Int. J. Climatol. 29, 2241 2255.

Marengo, J.A., Nobre, C.A., Tomasella, J., Oyama, M.D., Oliveira, G.S., Oliveira, R., Camargo, H., Alves, L.M., Brown, I.F., 2008. The drought of Amazonia in 2005. J. Climate 21, 495-516.

Mori, S.A., Becker, P., 1991. Flooding affects survival of Lecythidaceae in terra-firme forest near Manaus, Brazil. Biotropica 23, 87-90.

Nascimento, H.E.M., Laurance, W.F., 2004. Biomass dynamics in Amazonian forest fragments. Ecol. Appl. 14, S127-S138.

Negrón-Juárez, R.I., Chambers, J.Q., Guimarães, G., Zeng, H., Raupp, C.F.M., Marra, D.M., Ribeiro, G.H.P.M., Saatchi, S.S., Nelson, B., Higuchi, N., 2010. Response of tree biomass and wood litter to disturbance in a Central Amazon forest. Geophys. Res. Lett. 37, 1-5.

Nelson, B.W., Kapos, V., Adams, J.B., Oliveira, W.J., Braun, O.P.G., Amaral, I.L., 1994. Forest disturbance by large blowdowns in the Brazilian Amazon. Ecology 75, 853-858.

Nelson, B., 2005. Commentary: pervasive alteration of tree communities in undisturbed Amazonian forests. Biotropica 37, 158-159.
Nogueira, E.M., Nelson, B.W., Fearnside, P.M., 2005. Wood density in dense forest in Central Amazonia, Brazil. For. Ecol. Manag. 208, 261-286.

Phillips, O.L., Aragao, L.E.O.C., Lewis, S.L., Fisher, J.B., Lloyd, J., Lopez-Gonzalez, G., Malhi, Y., Monteagudo, A., Peacock, J., Quesada, C.A., van der Heijden, G., Almeida, S., Amaral, I., Arroyo, L., Aymard, G., Baker, T.R., Banki, O., Blanc, L., Bonal, D., Brando, P., Chave, J., de Oliveira, A.C.A., Cardozo, N.D., Czimczik, C.I. Feldpausch, T.R., Freitas, M.A., Gloor, E., Higuchi, N., Jimenez, E., Lloyd, G., Meir, P., Mendoza, C., Morel, A., Neill, D.A., Nepstad, D., Patino, S., Penuela, M.C., Prieto, A., Ramirez, F., Schwarz, M., Silva, J., Silveira, M., Thomas, A.S., ter Steege, H., Stropp, J., Vasquez, R., Zelazowski, P., Davila, E.A., Andelman, S., Andrade, A., Chao, K.J., Erwin, T., Di Fiore, A., Honorio, E., Keeling, H., Killeen, T.J., Laurance, W.F., Cruz, A.P., Pitman, N.C.A., Vargas, P.N., Ramirez-Angulo, H., Rudas, A., Salamao, R., Silva, N., Terborgh, J., Torres-Lezama, A., 2009. Drought sensitivity of the Amazon rainforest. Science 323, 1344-1347.

Piperno, D.R., Becker, P., 1996. Vegetation history of a site in the Central Amazon Basin derived from phytolith and charcoal records from natural soils. Quat. Res. 45, 202-209.

Platt, J.R., 1964. Strong inference. Science 146, 347-353.

Quesada, C.A., Lloyd, J., Schwarz, M., Baker, T.R., Phillips, O.L, Patiño, S., Czimczik, C.I., Hodnett, M.G., Herrera, R., Arneth, A., Lloyd, G., Malhi, Y., Dezzeo, N., Luizão, F.J., Santos, A.J.B., Schmerler, J., Arroyo, L., Silveira, M., Priante Filho, N., Jimenez, E.M., Paiva, R., Vieira, I., Neill, D.A., Silva, N., Peñuela, M.C., Monteagudo, A., Váquez, R., Prieto, A., Rudas, A., Almeida, S., Higuchi, N., Torres-Lezama, A., López-González, G., Peacock, J., Fyllas, N.M., Alvarez Dávilla, E., Erwin, T., Di Fiore, A., Chao, K.J., Honorio, E., Killeen, T.J., Peña Cruz, A., Pitman, N., Núñez Vargas, P., Salomão, R., Terborgh, J., Ramírez, H., 2009. Regional and large-scale patterns in Amazon forest structure and function are mediated by variations in soil physical and chemical properties. Biogeosci. Discuss. 6, 3993-4057.

Quesada, C.A., Lloyd, J., Anderson, L.O., Fyllas, N.M., Schwarz, M., Czimczik, C.I., 2011. Soils of Amazonia with particular reference to the rainfor sites. Biogeosciences $8,1415-1440$

R Development Core Team, 2009. R: A language and environment for statistical computing. R Foundation for Statistical Computing, Vienna, Austria. ISBN 3900051-07-0, URL <http://www.R-project.org>

Ribeiro, J.E.L.S., Hopkins, M.G., Vicentini, A., Sothers, C.A., Costa, M.A.S., Brito, J.M., Souza, M.A.D., Martins, L.H.P., Lohmann, L.G., Assunção, P.A.C.L., Pereira, E.C., Silva, C.F., Mesquita, M.R., Procópio, L., 1999. Flora da Reserva Ducke: guia de identificação das plantas vasculares de uma floresta de terra firme na Amazônia Central. INPA - UFAM, Manaus, Brazil.

Robert, A., 2003. Simulation of the effect of topography and tree falls on stand dynamics and stand structure of tropical forests. Ecol. Modell. 167, 287-303.

Schenk, H.J., Jackson, R.B., 2002. The global biogeography of roots. Ecol. Monogr. 72, 311-328.

Sheil, D., Burslem, D.F.R.P., Alder, D., 1995. The interpretation and misinterpretation of mortality rate measures. J. Ecol. 83, 331-333.

Souza, F.C., 2011. Dinâmica de uma floresta de terra firme na Estação Experimental de Silvicultura Tropical, Manaus - Amazonas. Master Thesis. Instituto Nacional de Pesquisas da Amazônia, Manaus.

Toledo, J.J., Magnusson, W.E., Castilho, C.V., Nascimento, H.E.M., 2011. How much variation in tree mortality is predicted by soil and topography in Central Amazonia? For. Ecol. Manag. 262, 331-338. <http://dx.doi.org/10.1016/ j.foreco.2011.03.039>.

Tomasella, J., Hodnett, M.G., Cuartas, L.A., Nobre, A.D., Waterloo, M.J., Oliveira, S.M., 2008. The water balance of an Amazonian micro-catchment: the effect of interannual variability of rainfall on hydrological behaviour. Hydrol. Process. $22,2133-2147$.

Williamson, G.B., Laurance, W.F., Oliveira, A.A., Delamonica, P., Gascon, C., Lovejoy, T.E., Pohl, L., 2000. Amazonian tree mortality during the 1997 El Niño drought. Conserv. Biol. 14, 1538-1542.

Young, T.P., Hubbell, S.P., 1991. Crown asymmetry, treefalls and repeat disturbance of broad-leaved forest gaps. J. Ecol. 72, 1464-1471.

Young, T.P., Perkocha, V., 1994. Treefalls, crown asymmetry, and buttresses. J. Ecol. $82,319-324$. 